\title{
PENGARUH MEDIA AUDIO VISUAL TERHADAP KEMAMPUAN MENULIS TEKS EKSPOSISI SISWA KELAS X SMK SATRIA NUSANTARA BINJAI TAHUN PELAJARAN 2019/2020.
}

\author{
Syafrizal $^{1}$ \\ M. Ali Sidiqin ${ }^{2}$ \\ Sawaludin Siregar, M.Pd. $\mathbf{I}^{3}$
}

\begin{abstract}
ABSTRAK
Penelitian ini bertujuan untuk mengetahui pengaruh media Audio Visual terhadap kemampuan menulis teks eksposisi siswa kelas X SMK (Sekolah Menengah Kejuruan). Penelitian ini dilaksanakan di SMK Satria Nusantara Binjai pada kelas X SMK Satria Nusantara Binjai Tahun Pelajaran 2019/2020. Populasi dan sampel yang dipilih adalah kelas X SMK yang berjumlah 30 siswa. Kelas yang dijadikan sampel untuk menentukan kelas yang diberi perlakuan (treatment ) menggunakan sistem pembelajaran dengan media Audio Visual. Pada tahap awal digunakan metode ceramah sebelum dikenakan perlakuan (treatment) untuk mengetahui tingkat penguasaan kemampuan menulis teks eksposisi siswa, kemudian tahap selanjutnya kelas eksperimen akan dikenakan perlakuan (treatmen) menggunakan media Audio Visual dalam jangka waktu tertentu. Kemudian perlakuan tersebut diukur. Disain penelitian yang digunakan dalam penelitian ini adalah pretest posttest dengan menggunakan metode Nonequivalent Control Group Design. Penelitian ini dapat digolongkan ke dalam penelitian eksperimen semu (quasi eksperiment). Penelitian ini melibatkan dua jenis instrumen yaitu tes uraian dan tes menulis eksposisi. Instrumen dalam bentuk tes uraian digunakan untuk mengukur kemampuan dalam penyelesaian soal. Sedangkan instrumen dalam bentuk tes menulis terdiri dari skala pemahaman siswa terhadap kemampuan menulis eksposisi. Dari hasil perhitungan diperoleh $t_{\text {hitung }}=3,52$ Sedangkan $t_{\text {tabel }}=2,0399$ pada taraf signifikan $\alpha=0,05$ dengan derajat kebebasan $=58$, Berarti $t_{\text {hitung }}>t_{\text {tabel }}$ yang menyatakan $H_{o}$ ditolak dan $H_{1}$ diterima. Ini menunjukkan bahwa terdapat pengaruh terhadap kemampuan menulis teks eksposisi dengan menggunakan model pembelajaran menggunakan media Audio Visual siswa kelas X SMK Satria Nusantara Binjai Tahun Pelajaran 2019/2020.
\end{abstract}

Kata Kunci: Media Audio Visual, menulis teks eksposisi 


\section{PENDAHULUAN}

Pelajaran bahasa Indonesia diharapkan dapat menghasilkan siswa yang memiliki kemampuan dalam menggunakan keterampilan berbahasa, terutama dalam hal menulis untuk menggali ide-ide dan menerapkan ilmu pengetahuan melalui bahasa tulis dan bahasa lisan yang tersusun secara sistematis.

Bahasa Indonesia tidak hanya sebagai sarana untuk membicarakan ilmu pengetahuan, tetapi juga sebagai sarana untuk mengembangkan dan menyampaikan ilmu pengetahuan itu sendiri dari generasi ke generasi, menjadi sarana untuk berfikir dan mengembangkan minat peserta didik untuk menyampaikan gagasan-gagasan dan sebagai alat untuk berkomunikasi melalui bahasa lisan maupun bahasa tulisan.

Untuk menyampaikan dan membicarakan bahasa sebagai alat penyampai informasi secara lisan maupun tulisan dengan baik, maka dalam dunia pendidikan penting untuk melatih kemampuan siswa dalam hal menulis sehingga tulisan dapat tersusun dengan menggunakan bahasa yang menarik dan mudah difahami dalam menyampaikan ide-ide dan pengetahuan sebagai informasi kepada seseorang.

Nurgiantoro berpendapat bahwa, "kemampuan menulis lebih sulit dikuasai dibanding tiga kemampuan berbahasa yang lain bahkan oleh penutur asli bahasa yang bersangkutan sekalipun".

Kemampuan diartikan sebagai kesanggupan untuk melakukan sesuatu yang didapat secara tidak sadar. Kemampuan berasal dari kata dasar "mampu", dalam bahasa Inggris kemampuan adalah ability.

Pendapat tersebut didukung oleh Semi yang menyatakan bahwa,"kemampuan adalah kesanggupan untuk menghasilkan atau melakukan sesuatu". Sejalan dengan pendapat Semi, Moeliono juga menyatakan bahwa,"kemampuan diartikan sebagai kesanggupan atau kecakapan".

Selain itu Tarigan mengemukakan bahwa:

Kompetensi kemampuan diartikan sebagai pengetahuan yang dipunyai pemakai bahasa tentang bahasanya, nilai-nilai yang merupakan objek penting. Kemampuan ialah pengetahuan yang asli yang dimulai individu secara tidak sadar, secara diam-diam, secara intrinsik, implisit, dan terbatas.

Menurut Thoha dalam moenir, "kemampuan merupakan salah satu unsur dalam kematangan berkaitan dengan pengetahuan atau keterampilan yang dapat diperoleh dari pendidikan, pelatihan dan suatu pengalaman". ${ }^{1}$ Wikipedia, "kemampuan adalah sebuah penilaian terkini atas apa yang dapat dilakukan seseorang".

Hal itu disebabkan kemampuan menulis menghendaki penguasaan berbagai unsur di luar bahasa itu sendiri yang akan menjadi isi karangan baik unsur bahasa maupun unsur isi haruslah terjalin sedemikian rupa sehingga menghasilkan karangan yang runtut dan padu.

Salah satu cara untuk membuat siswa menjadi produktif, kreatif, inovatif, dan afektif adalah dengan pembelajaran menulis teks eksposisi yang mengharuskan siswa berfikir kritis dan menghasilkan sebuah tulisan yang memberikan penjelasan atau pemaparan suatu hal dengan gaya penulisan yang singkat, jelas, dan padat.

Selain itu, pembelajaran menulis eksposisi diajarkan pada siswa kelas X SMK (Sekolah Menengah Kejuruan) pada materi menulis teks eksposisi. 
Tarigan mengemukakan bahwa, "menulis merupakan kemampuan berbahasa yang dipergunakan untuk berkomunikasi secara tidak langsung, dengan kata lain tidak secara tatap muka dengan orang lain”. Menulis merupakan salah satu kegiatan produktif dan ekspresif.

Menurut Nurgiyantoro menulis merupakan proses pengungkapan ide, gagasan, pikiran, maupun perasaan yang dituangkan melalui tulisan. Kompetensi menulis lebih sulit dibanding tiga kompetensi bahasa yang lain”.

Imron mengatakan, "menulis adalah kegiatan menuangkan ide, gagasan, konsep, pikiran, ataupun imajinasi ke dalam bentuk tulis (cetak)".

Karangan eksposisi mengandung masalah yang dikomunikasikan dalam bentuk pemberitahuan dan informasi. Tujuan utama penulisan eksposisi itu hanya untuk membagikan informasi dan tidak sama sekali untuk mendesakkan atau memaksakan orang lain agar menerima pandangan atau pendirian tertentu.

Menurut Keraf bahwa, "eksposisi atau pemaparan adalah salah satu bentuk tulisan atau retorika yang berusaha untuk menerangkan dan menguraikan suatu pokok pikiran, yang dapat memperluas pandangan atau pengetahuan seseorang yang membaca uraian tersebut". ${ }^{2}$

Dengan demikian, teks eksposisi adalah suatu bentuk tulisan yang berusaha menerangkan sesuatu benda, manusia, hewan, tumbuh-tumbuhan, fenomena alam, dan peristiwa yang bersifat informatif, secara terperinci tentang ciri-ciri atau bagian-bagian yang merupakan pengenal dari suatu obyek dalam bentuk tulisan maupun lisan.

Keterampilan menulis dalam dunia pendidikan memegang peranan penting dan merupakan suatu klimaks dari beberapa keterampilan berbahasa. Menulis sebagai sarana untuk menyampaikan ide-ide bermakna dari suatu pemikiran yang bertujuan menyampaikan informasi dan pengetahuan sehingga bermanfaat bagi diri sendiri dan orang lain.

Salah satu cara untuk membuat siswa menjadi produktif, kreatif, inovatif, dan afektif adalah dengan pembelajaran menulis teks eksposisi yang mengharuskan siswa berfikir kritis dan menghasilkan sebuah tulisan yang memberikan penjelasan atau pemaparan suatu hal dengan gaya penulisan yang singkat, jelas, dan padat.

Pada prinsipnya fungsi utama dari tulisan sebagai alat komunikasi yang tidak langsung. Menulis juga sangat penting bagi pendidikan karena memudahkan para pelajar berpikir secara kritis, memudahkan merasakan dan menikmati hubungan-hubungan, memperdalam daya tanggap, memecahkan masalah.

Namun pada praktiknya, kondisi siswa dalam melaksanakan pembelajaran menulis teks eksposisi masih jauh dari apa yang diharapkan, rendahnya kemampuan siswa dalam menulis teks eksposisi, siswa kurang berminat dalam mengikuti pembelajaran menulis teks eksposisi, siswa sulit menemukan ide dalam menulis teks eksposisi.

Hal ini, terlihat dari hasil pembelajaran yang tidak memuaskan. Sebagian siswa mendapatkan nilai di bawah KKM (Kriteria Ketuntasan Minimal) yang telah ditetapkan, yaitu nilai 75. Selain itu, siswa kurang tertarik dan merasa bosan untuk mengikuti pembelajaran materi menulis teks eksposisi karena kurangnya penggunaan media yang tidak sesuai dengan situasi dan kondisi siswa ketika melaksanakan proses pembelajaran.

Pemahaman siswa yang masih kurang dalam menulis teks eksposisi merupakan suatu kendala dalam pembelajaran bahasa Indonesia. Perkembangan kemampuan siswa dalam 
menulis semakin hari semakin menurun. Siswa membutuhkan proses belajar yang menarik dan tidak membosankan, karena model pembelajaran yang monoton sehingga siswa cepat merasa jenuh pada saat pembelajaran berlangsung.

Kurangnya minat siswa dalam mengikuti pembelajaran, maka menjadi suatu permasalahan bagi siswa untuk mencapai tujuan pembelajaran yang diharapkan tentunya perlu dicari dan diambil solusinya. Salah satu solusi yang layak untuk diupayakan dalam pencapaian tujuan pembelajaran yang optimal adalah dengan menggunakan media.

Soeparno menyebutkan bahwa, "media adalah suatu alat yang dipakai sebagai saluran (channel) untuk menyampaikan suatu pesan (message) atau informasi dari suatu sumber (resource) kepada penerimanya (receiver)". Guru seringkali menjadi sumber informasi dan siswa sebagai penerima dalam pembelajaran di kelas.

Dengan demikian, media adalah suatu sarana untuk mempermudah penyampaian maksud dan tujuan seseorang kepada orang lain sehingga orang lain faham terhadap apa yang disampaikan. Media bermanfaat untuk melatih siswa dalam hal memahami suatu informasi sehingga jelas maksud dan maknanya.

Penggunaan media audio visual suatu cara yang efektif untuk mempermudah pemahaman siswa dalam mememahami materi yang disampaikan guru karena materi dapat dilihat dan didengar langsung oleh siswa sesuai dengan pengalaman yang dialami oleh siswa.

Menurut Suleiman alat-alat audio-visual adalah alat-alat yang "audiable" artinya dapat didengar dan alat-alat yang "visible" artinya dapat dilihat. Alat audio-visual berguna untuk membuat cara berkomunikasi menjadi efektif.

Media sendiri masih terbagi dalam beberapa jenis, salah satunya adalah audiovisual. Video merupakan salah satu bentuk dari media audio-visual. Video mengandung gambar bergerak yang bisa dilihat dan suara untuk didengar. Kombinasi audio dan visual biasa menjadi salah satu cara efektif dalam proses belajar bagi siswa.

Beberapa siswa dapat belajar melalui audio, beberapa lainnya melalui visual, atau bahkan keduanya. Menurut Daryanto bahwa,"media video adalah segala sesuatu yang memungkinkan sinyal dapat dikombinasikan dengan gambar bergerak secara konsekuensial”.

Pembelajaran ini berbeda dari pembelajaran sebelumnya, pembelajaran sebelumnya siswa cenderung bersifat lebih fasif, kurang berminat dalam mengikuti proses belajar mengajar, cepat merasa bosan dengan materi yang disampaikan oleh guru di sekolah.

Namun, melalui penggunaan media audio visual siswa diupayakan mampu merespon materi yang disampaikan guru mengenai pengetahuan-pengetahuan yang dimiliki dengan pengalaman-pengalaman yang dilihat atau yang dialaminya sehingga proses belajar mengajar terasa lebih menarik dan lebih berkesan bagi siswa. Penggunaan media audio visual mampu menarik minat belajar siswa dalam mengikuti proses pembelajaran menulis teks eksposisi siswa.

Dalam tahap ini dilakukan saat pramenulis. Media audio visual diperbantukan dalam menarik minat siswa karena dalam karangan eksposisi siswa perlu menelaah sebuah kejadian. Media yang diputarkan merupakan kejadian yang dekat dengan siswa sehingga mudah untuk dipahami.

Proses selanjutnya, siswa menulis karangan eksposisi dengan tahap membuat draf, merevisi, menyunting, dan publikasi. Pengaruh media audio visual kali ini akan difokuskan pada pembelajaran menulis karangan eksposisi. Oleh karena itu, penulis mencoba menguji keefektifan pengaruh media 
audio visual dalam pembelajaran menulis teks eksposisi.

\section{METODE PENELITIAN}

\section{Jenis Penelitian}

Jenis penelitian ini termasuk jenis penelitian eksperimen semu atau quasi eksperiment, pada penelitian ini, populasi dapat dikategorikan heterogen.

Populasi dalam penelitian ini adalah seluruh siswa kelas X SMK Satria Nusantara Binjai yang berjumlah 30 siswa.

Tabel 3.2 Populasi Penelitian

\begin{tabular}{cccc}
\hline \multicolumn{4}{c}{ Siswa } \\
\hline Kelas & L & P & Jumlah \\
\hline$X$ & 23 & 7 & 30 \\
\hline
\end{tabular}

Dari satu kelas pupulasi, diambil siswa kelas X SMK seluruhnya. Satu kelas yang dijadikan sampel diberikan perlakuan (treatment) sebuah pembelajaran menggunakan media audio visual. Sampel dalam penelitian ini berjumlah 30 siswa.

Tabel 3.3 Sampel Penelitian

\begin{tabular}{|c|c|c|c|}
\hline & \multicolumn{2}{|c|}{ Siswa } & \\
\hline Kelas & L & P & Jumlah \\
\hline $\mathrm{X}$ & 23 & 7 & 30 \\
\hline
\end{tabular}

Selain itu, pada quasi eksperiment juga tidak dapat dilakukan pengontrolan terhadap semua variabel luar yang dapat mempengaruhi jalannya penelitian. Untuk subjek penelitian, penelitian dilakukan berdasarkan kelompok yang telah terbentuk sebelumnya atau kelompok yang telah ada.

Kelompok perlakuan ini disebut juga kelas eksperimen atau kelompok eksperimen, yaitu merupakan penelitian yang dimaksudkan untuk mengetahui ada tidaknya pengaruh dari sesuatu yang dikenakan pada siswa sebagai subjek penelitian.
Pengaruh yang dimaksudkan adalah penggunaan pembelajaran dengan menggunakan media audio visual terhadap kemampuan menulis teks eksposisi siswa yang telah ditentukan dan dapat dilihat dari hasil jawaban siswa pada tes hasil belajar.

\section{Desain Penelitian}

Penelitian ini melibatkan satu kelas yang diberi perlakuan yang sama. Desain penelitian ini menggunakan metode Nonequivalent Control Group Design. Pendekatan kuantitatif digunakan agar semua gejala yang diobservasi dapat diukur dan diubah dalam bentuk angka-angka sehingga memungkinkan digunakan analisis statistik.

Perlakuan yang dimaksud dalam penelitian ini adalah penggunaan media audio visual untuk mendukung keterampilan menulis teks eksposisi siswa kelas X SMK Satria Nusantara Binjai. Subjek penelitian ini terdiri dari satu kelas, yakni kelas X SMK.

Pada tahap awal digunakan metode ceramah sebelum dikenakan perlakuan (treatment) untuk mengetahui tingkat penguasaan kemampuan menulis teks eksposisi siswa, kemudian tahap selanjutnya kelas eksperimen akan dikenakan perlakuan (treatmen) menggunakan media audio visual dalam jangka waktu tertentu. Kemudian, kedua perlakuan ini diukur untuk dibandingkan. Disain penelitian yang digunakan dalam penelitian ini adalah pretest posttest.

\section{HASIL DAN PEMBAHASAN}

\section{Uji Normalitas}

Uji normalitas dihitung dengan menggunakan Liliefors, dari data hasil kemampuan berbicara siswa untuk kelas kontrol diperoleh data $\mathrm{L}_{\text {hitung }}=0,1517, \mathrm{~L}_{\text {tabel, }}$ untuk $\mathrm{n}=30$ dengan taraf signifikan 0,05 adalah 0,161 . L $_{\text {hitung }}<\mathrm{L}_{\text {tabel, }}$ ( Lampiran $4 \mathrm{hlm}$ 48), sedangkan untuk kelas eksperimen 
diperoleh nilai $\mathrm{L}_{\text {hitung }}=0,1375, \mathrm{~L}_{\text {tabel }}$ untuk $\mathrm{n}=$ 30 dengan taraf signifikan 0,05 adalah 0,161. $\mathrm{L}_{\text {hitung, }}<\mathrm{L}_{\text {tabel, }}$ Sehingga dapat disimpulkan bahwa data kemampuan menulis karangan narasi siswa untuk kelas kontrol dan kelas eksperimen berdistribusi normal.

\section{Hasil Perhitugan Uji Normalitas}

\begin{tabular}{ccc}
\hline Sampel & $\mathbf{L}_{\text {hitung }}$ & $\mathbf{L}_{\text {tabel }}$ \\
\hline $\begin{array}{c}\text { Pendekatan } \\
\text { Konvensional (X) }\end{array}$ & 0,1517 & 0,161 \\
\hline $\begin{array}{c}\text { Pendekatan } \\
\text { Komunikatif (Y) }\end{array}$ & 0,1375 & 0,161 \\
\hline
\end{tabular}

\section{Uji Homogenitas}

Uji homogenitas atau uji kesamaan dua varian populasi dari dua kelompok dilakukan dengan uji fisher. Dari hasil pengujian diperoleh $F_{\text {hitung }} 1,23$ dan $F_{\text {tabel }}$ 1,83 pada taraf signifikan 0,05 dengan dk pembilang $=29$ dan dk penyebut $=29$. karena $F_{\text {hitung }}<F_{\text {tabel }}$ maka dapat disimpulkan bahwa varian kedua kelompok tersebut homogen.

Tabel 4.12 Hasil Hitung Uji Homogenitas

\begin{tabular}{cc}
\hline $\mathbf{F}_{\text {hitung }}$ & $\mathbf{F}_{\text {tabel }}$ \\
\hline 1,23 & 1,85 \\
\hline
\end{tabular}

\section{Pengujian Hipotesis}

Hipotesis yang diuji adalah :

Keterangan :

$\mathrm{H}_{0}: \mu_{1} \leq \mu_{2}$

$\mathrm{H}_{1}: \mu_{1} \geq \mu_{2}$

$\mathrm{H}_{0}$ : Tidak terdapat pengaruh media audio visual terhadap kemampuan menulis teks eksposisi siswa kelas X SMK Satria Nusantara Binjai.

$\mathrm{H}_{1}$ : Terdapat pengaruh media audio visual terhadap kemampuan menulis teks eksposisi siswa kelas X SMK Satria Nusantara Binjai.

Untuk menguji hipotesis yang telah dirumuskan, maka dilakukan perhitungan diperoleh $\mathrm{t}_{\text {hitung }}=3,52$ sedangkan $\mathrm{t}_{\text {tabel }}=2,0399$ pada taraf signifikan $\alpha=0,05$ dengan derajat kebebasan $=58$. Berarti $t_{\text {hitung }}>t_{\text {tabel }}$ yang menyatakan $\mathrm{H}_{0}$ ditolak $\mathrm{H}_{1}$ diterima. Ini menunjukkan bahwa terdapat pengaruh yang signifikan antara kelas eksperimen terhadap kemampuan menulis teks eksposisi siswa dengan menggunakan media audio visual siswa kelas X SMK Satria Nusantara Binjai. 


\section{KESIMPULAN}

Berdasarkan hasil pengujian hipotesis, terdapat pengaruh yang sangat besar pada kemampuan menulis teks eksposisi dengan menggunakan media audio visual dibandingkan dengan menggunakan metode konvensional. Data tersebut menunjukkan bahwa dengan menggunakan media audio visual hasil kemampuan menulis teks eksposisi siswa lebih besar.

Analisis yang telah dilakukan dan telah diuji secara statistik didapat bahwa $t_{\text {hitung }}$ lebih besar dari $t_{\text {tabel }}(3,52>2,0399)$ yang menyebabkan $\mathrm{H}_{0}$ ditolak dan $\mathrm{H}_{1}$ diterima. Dengan demikian dapat disimpulkan bahwa terdapat pengaruh kemampuan menulis teks eksposisi siswa menggunakan media audio visual di kelas X SMK Satria Nusantara Binjai.

\section{DAFTAR PUSTAKA}

Daryanto. 2010. Media Pembelajaran, Yogyakarta: Penerbit Gava Media.

Daryanto.2017. Media Pembelajaran, Bandung: Satu Nusa.

Gibson \& Ivancevich \& Donnely. 1994. Organisasi dan manajemen. Perilaku, struktur, proses. Edisi keempat. Jakarta: Erlangga.

Keraf Gorys. 1982. Eksposisi dan Deskripsi. Ende: Nusa Indah.
Moeliono, M. Anton, dkk. 2008. Kamus Lengkap Bahasa Indonesia. Jakarta: Balai Pustaka.

Nurgiantoro Burhan, dkk. 2009,Statistik Terapan untuk Penelitian Ilmu-ilmu Sosial. Yogyakarta: Gajah Mada University Press.

Nurgiyantoro, Burhan. 2013. Penilaian Pembelajaran Bahasa Berbasis Kompetensi. Yogyakarta: BPFE.

Rosidi Imron. 2009. Menulis, Siapa Takut. Yogyakarta: Kanisius.

Semi Atar M. 2005. Menulis Efektif. Padang: Angkasa Raya.

Suleiman Hamzah Amir. 1985. Media Audio Visual untuk Pengajaran, Penerangan dan Penyuluhan, Jakarta: Gramedia.

Suparno. 1988. Media Pembelajaran Bahasa. Yogyakarta: PT Intan-Pariwara.

Tarigan Guntur Henry. 2007. Membina Keterampilan Menulis Paragraf. Bandung; Angkasa.

Tarigan Guntur Henry. 2008. Menulis Sebagai Suatu Keterampilan Berbahasa. Bandung: Angkasa.

Wikipedia. Kemampuan, di unduh tanggal 17Maret 2019 pukul $20.00 \mathrm{Wib}$ 